\title{
PALINDROMES AND LETTER \\ FORMULAE: SOME \\ RECONSIDERATIONS
}

\section{Mare Kõiva}

The article is based on the collection of incantations in the Estonian Folklore Archives and it aims to provide a description of an old and less-known type of incantations in Estonia. The term "letter formulae" will hereafter be used to designate incantations based on letters or letter combinations, palindromes, other formulae connected with letter mythology, and also names which function as spells. In general it can be said that this originally old type of incantations has reached this cultural area relatively late. A majority of the formulae are more or less directly connected with cabalism, the connection is genetic and the formulae spread through the mediation of cabalism. The formulae reached Estonia through secondary manuscripts and it is not likely that at that time any Estonian folk doctors/healers would have been familiar with the cabala; neither were proper names attributed meanings and values characteristic of occult sciences.

Letter formulae and independent incantations have been distinguished as a separate subgroup of spells. Karlis Straubergs has referred to letter formulae as cabalistic texts (Straubergs 1939: $270 \mathrm{ff}$.). Generically scholars have used the name of one of the most wide-spread incantations abrakadabra (Astakhova 1928: 50 ff., Poznanski 1917, 58 ff., Peskov 1977, 38, Gagulashvili 1983, 104 ff.). In standard language the word has gradually taken on the meaning of the unknown and the unintelligible.

Alongside with incantations directly based on letter magic some researchers have included into this subgroup incantations which at the first glance seem semantically and logically incomprehensible. Examples of such formulae are "The dog is white, the cat is gray - all one family of snakes" (Peskov 1977: 38) and incantations employing foreign words in original or distorted shapes (Gagulashvili 1983: 105). 
Here the notion of letter formula will cover but the above-mentioned phenomena. Incantations containing distorted word forms and wholly foreign-language incantations are classifiable by other formal criteria and will not be discussed at this point.

\section{MAIN TYPES OF LETTER FORMULAE}

As indicated above, most letter formulae are the so-called letter quadrates consisting of vowels, consonants or letters which may but need not make up meaningful words. The group also comprises letter abbreviations derived from prayers, incantations composed of special meaningless spells and sacral names. A pervasive characteristic of all these formulae is the fact that in addition to a linear representation there were frequent attempts at graphic design of the text, it was mostly laid out in circles, quadrangles, labyrinths, the image of the Sun, etc. and the text was complemented with magic signs, loops or surrounded, for example, with circles.

In principle the quadrangles are palindromes, a closed circle where every single letter and word may have a specific meaning. Mostly just one palindrome was used during incantation, but occasionally palindromes have been mirrored horizontally or vertically due to various magical considerations and in order to increase the power of the incantation.

The most oldest and best-known palindrome in Estonia is sator (Map 1). Sator has been interpreted as a formula based on a game

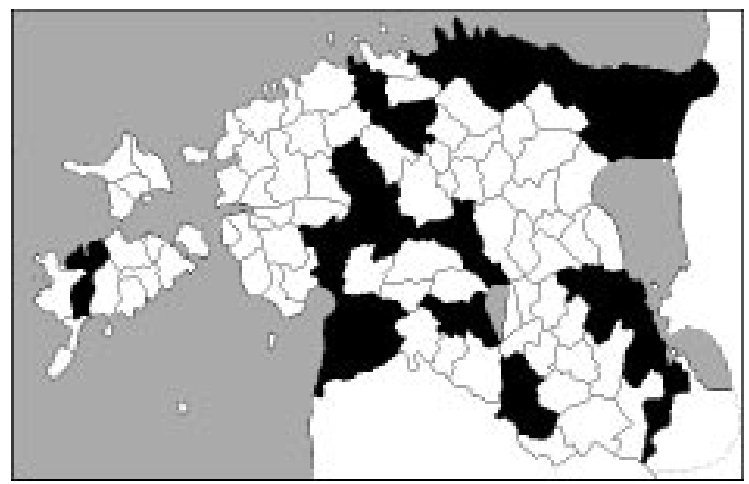

Map 1. Distribution of the sator-formula in Estonia. 
with sacred names (Seligman 1910: 300), as a magic alphabetic quadrangle (Dornseiff 1985), and as a Latin maxim (Eisen 1934). The sator formula has been found in Coptic scrolls, in the Middle Ages it has been used by Muslims and cabalists (Dornseiff 1985: 79). The formula has comfortably established itself in the European tradition of incantation, and due to its impressive form and significant function it has been repeatedly published in various esoteric manuscripts. In the 18th century at the apogee of the use of the formula, the incantation was attached to planks, clay tablets or plates that were put up on the walls of houses or outhouses. At times of war and extensive fires such incantations were burnt in order to prevent fire.

The Estonian language in general does not favour palindromes, which is why only a few original palindromes could be found in Estonian, for example aias sadas saia ('it rained white bread in the garden'). Except for incantations even the folk tradition lacks of palindromes based on word combinations or abbreviations.

In Estonian, sator-words were commonly written in quadrangles and capital letters, the latter were separated by punctuation:

$$
\begin{aligned}
& \text { S.A.T.O.R } \\
& \text { A.R.E.P.O } \\
& \text { T.E.N.E.T } \\
& \text { O.P.E.R.A } \\
& \text { R.O.T.A.S }
\end{aligned}
$$

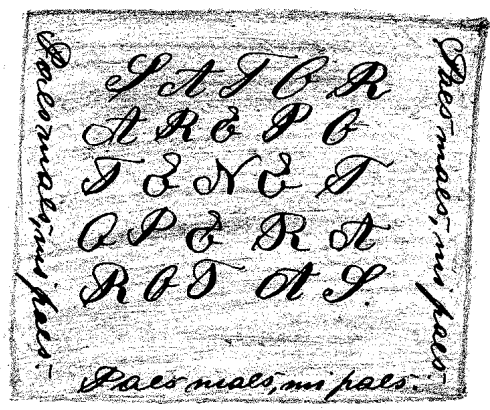

Drawing 1. An erysipelas-paper. ${ }^{\prime}$ 7, $382(7)<$ Vil1895. 
Alongside with the latter also small-letter quadrangles and quadrangles combining small letters with capitals were used either intermittently or at random (Eisen 1934: 89). Most commonly only one formula was written for the healing rite. However, in some cases two formulae were written side by side, one mirroring the other beside or opposite it. The mirroring of formulae has mostly been connected with an indirect attempt to influence the disease demon and force it to leave or revert itself (Dornseiff 1985: 56).

SADOR RODAS
ARPOT DORPA
TENET TENET
OPRAT TARPO
ROTAS SATOR (E $9175(19)<$ Vil 1894)

Such an incantation in the form of a magic quadrangle could be on all four sides surrounded by either specific meaningless magic words or other palindromes, for instance, a version of the rosa pilla formula. The result was an image roughly resemblant of a cross - one of the early ways of representing letter formulae. A similar way was used to write INRI, the abbreviation for the name of Christ and other formulae. Besides the use of the cross-shape there is the early tradition used already in ancient Greece and Rome of writing the formula in the form of a circle or encircling it. Alternatively the formula could be written simply as a sequence of letters (H I 7, $265<$ Vil 1895).

In European tradition the sator-formula was mostly used as a protection against fire; in Estonia it was the best-known incantation against erysipelas, also used against rabies and less frequently against fire. There are single accounts about its use in hunting magic, as words against the wrath of the landlord, bone-ache, snakebite, swelling, toothache, and to stop bleeding. Such multifunctionality is an advantage of certain early incantations which have either been of universal use or have gradually enlarged their area of use.

It seems that early incantations are distinguished by their ability to append other incantations, thus forming longer and more complex new units. In most cases the sator-formula was used alone but could also be appended with other spells, even those of quite differ- 
ent form. A complete incantation was made up of either combined letter formulae (LF); legend incantations (ILeg) combined with letter formulae; letter formulae and short formulae of biblical background (FBibSht); extracts from psalms or prayers (Ps/Pr) and letter formulae; letter formulae and short incantations (ISht); and extremely rarely also letter formulae combined with spells in the form of runo song (Reg). Two to four independent incantations could contaminate usually taking on parts serving as commencement or reinforcement incantations; e.g.: "Maks, Paks" + "Sator" + "Mene, tekel" $(\mathrm{LF}+\mathrm{LF}+\mathrm{LF})$; "Three sisters putting out a fire" + "Sator" (ILeg+LF); "Sator" + "Mene, tekel" + "When Jesus was crucified" + "All dear blessing of the soul" (LF+LF+ILeg+Ps/Pr); "Sator" + "Off with you, pain" (LF+FBibSht/ISht); "Sator" + "In the name of the Holy Trinity" + "Sator" + "Rosa pilla" (LF+FBibSht/ISht+LF+LF); "Sator" + "Master the man, lady the woman" (LF+R); "Sator" + "Rosa pilla" ( $\mathrm{LF}+\mathrm{LF})$. A compound incantation is usually composed of written incantations ("Mene, tekel", "Rosa pilla"), or both read and written incantations were appended to the written part. This phenomenon will receive closer attention in the section dealing with ways of performing. Variants of the formula differ by letter omissions and replacements but it is likely that the need to retain a palindrome worked against the development of larger deviations.

Another wide-spread palindrome is rosa pilla with the full name of rosabillaallibasor (Map 2). The way of writing and graphical shape of the formula are more varied than in the case of sator. Written

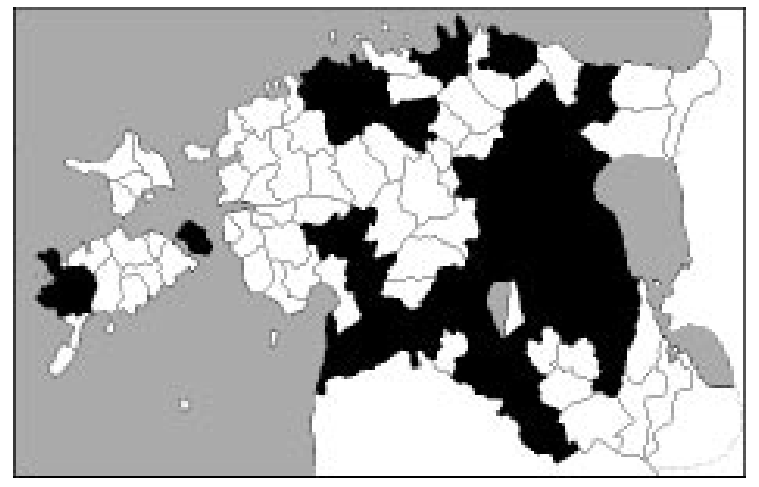

Map 2. Distribution of the rosa pilla-formula. 


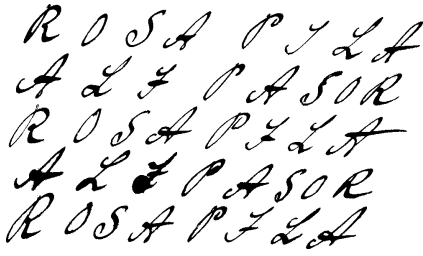

Drawing 2. ERM $95<$ Puh.

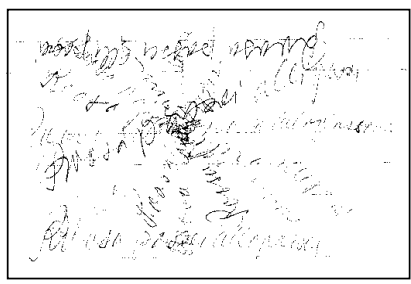

Drawing 3. ERA II 208, 369/ $70(25)<\operatorname{Trm} 1938$.

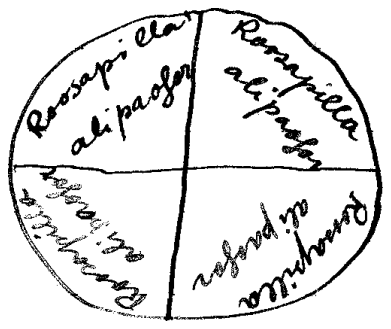

Drawing 4. ERA II 123, 513 (9) < Trv 1936. sequentially it is a pure palindrome, but actually the formula was often written in two-word sets (thus again as a quadrangle) beneath one another in two, three or four rows, in the form of a circle, or in a sextuple or octuple interdigitation, whereas the text was encircled with one or more circles. These are some basic ways of writing magic texts used already in early Coptic manuscripts. There are rare cases where the so-called hyphenated formula consisting of two plus two words has been repeated thrice, one part under another, forming a quadrangle. The formula was contaminated with a couple other letter formulae, first of all sator and sieht stiets and was used for treating erysipelas. Variations in the text seem to be a result of an attempt to adapt incomprehensible foreign words to the mother tongue and to make them possibly more understandable. There are cases where the rhythm of a newer song has influenced the formula; in some instances there has been a simple change of letters. The following example serves to illustrate the range of variations of one formula: roosaprilla; roosa lilla alli karva; roosa prilla, hallipea sorr; roosa prilla aabassoora; roosa palla, vaasa alla; roos pill alla; roos pill ja alla; rõssa, pella, pastor; ai lilla, roosapilla; aali roosa, roosa piire aita sina; roosa alla; roosa pilla, alla roosa; rossi lilla alli passo vatta; roosavilla allivasoor; roos ramp; roosa pilla, alla passa; alepasuur; TALPZOR ROSZPLAT.

Besides letter formulae $(\mathrm{LF}+\mathrm{LF})$ the main formula could be appended by 
popular short incantations of exorcism (LF+ISht). For example:

Get lost as an old moon from the sky; Go to where you came from! Get out! In the name of Father, Son and the Holy Ghost, alla rosa, amen; you help, I shall not help.

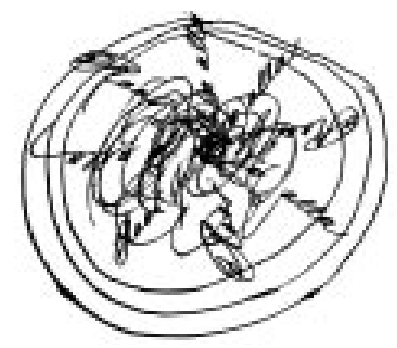

But there are also longer extracts close to epic incantations $(\mathrm{LF}+\mathrm{E})$. For example:

Meie issand Jeesus Kristus. Mine välja!

Mine välja lõuna ajal kolmapäeval Liisa Antoni seest! Aamen!
Our Lord Jesus Christ. Go out!

Go out of Liisa Anton Amen!

Drawing 5. H II 33, 367 (1) $<\operatorname{Kod} 1889$.

(RKM II 362, $22(20)<\operatorname{Trv} 1981)$

Similarly were appended revile formulae and short incantations, for example Rubbish, rubbish roosipila! I shall shut you up! In the name of God the Father, the Son and the Holy Ghost or even runo song like exorcisms originally meant against swelling and dermatological diseases $(\mathrm{LF}+\mathrm{R})$. For example:

/--- /

Kui haige, siis alane, kui paiste, siis parane! Alt juureta, pealt ladvata kes ihu peale puhtaks. (E $59165<$ Kod 1921)

$$
\text { /---/ }
$$

If sick, decline, if swollen, get well! With no root below, with no top above your skin gets clean.

In Estonia were also used palindromic amor-words with parallels known only in the Baltics, though probably once known in a wider area (Map 3).
$A+M+O+R$
$M+I+L+O$
$O+L+I+M$
$R+O+M+A$
(E $9174(17)<$ Vil $)$ 


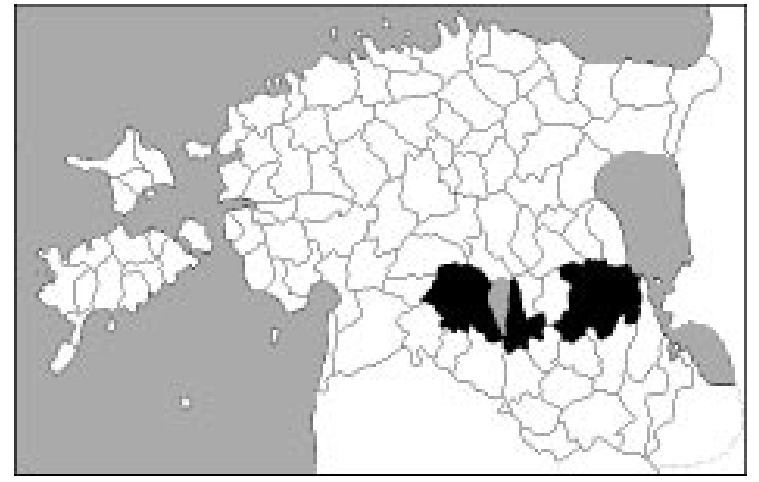

Map 3. Distribution of amor-milo.

The formula has been recorded in a narrow area in South Estonian counties (Tartu and Viljandi counties) and it was used against rabies, according to single accounts also against erysipelas, bone-ache and in love magic. It is possible that the latter area of use was influenced by the literal meaning of the word amor. On Latvian territory the word has been used to treat erysipelas (Straubergs 1939: 274). Amor-milo was not appended with other incantation types.

Other letter combinations were also used: consonant clusters or quadrangles made up of consonants such as $t: b: t: f$ to heal erysipelas and use at childbirth, and $X X X$ for use in stock-raising. The following is an example of such erysipelas words:

$t: b: t: f:$

$t: d: t: t: t:$

$\operatorname{Tr}: t: b: t: g:$

$T: z: t: t: \operatorname{Tr}:$

$t: b: t: d: t$ :

$A: f: M: t:$

(SKS, Niemi II No. $1103<$ Kär 1893)

Estonian and Baltic-Finnic traditions do not employ extending quadrangles; of contracting quadrangles or incantations, where the number of letters was decreased in every successive link, only abrakadabra was known in Estonian area (Map 4). It is first mentioned by Quintus Serenus Sammonicus in 200 A.D. This in- 


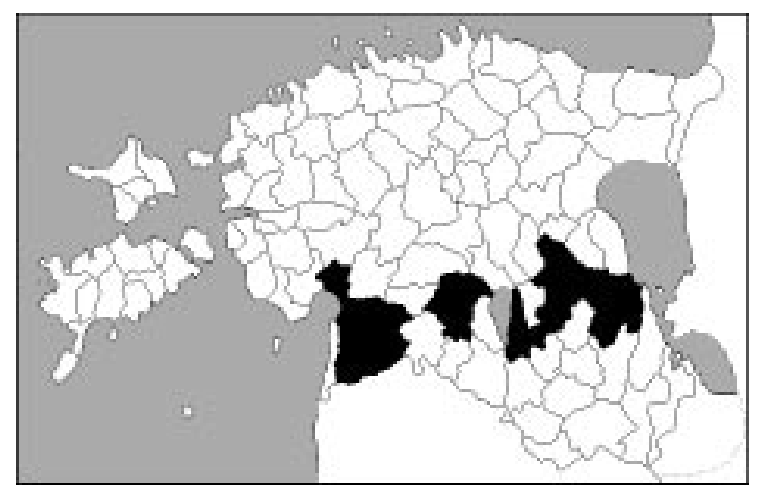

Map 4. Distribution of abrakadabra.

cantation has been interpreted as a formula derived from the holy name of God (the seven-letter word Abraxas, the constituent letters of which sum up as 365 or the number of days in a year) (Wuttke 1925: 181, Seligmann 1910, 299). Many nations have usedAbraxas as an independent incantation. Another explanation for the formula derives from the Hebraic expression "Father, Son and the Holy Ghost" (ab - father, ben - son, ruach - ghost) and the expression "Take away" (Hndb I 1698), which allegedly refers to the gradual deletion of letters in the quadrangle.

In times of limited literacy knowing of the whole alphabet was a privilege of selected few, and the alphabet itself was seen as having magical powers. This is why F. Dornseiff has interpreted abrakadabra as a magical alphabet (1985: 64). Other better-known connections include the interpretation of writing of the seven-letter (the planets) amulet connected, through the mediation of Abraxas, with Hellenic witchcraft formulae and Tetragramaton, with the quadruple figure as a game denoting God.

In Europe, abrakadabra was used against fever and toothache, to heal wounds, and also in making butter. In Estonia it has been used as a healing incantation against rabies, malaria, and according to one account also to heal nari (inflammation of wrist joint). The words were used in a relatively small area (Tartu, Viljandi and Pärnu counties); in the same area differences in texts and graphical representations have been recorded:abrakadabra is found 
as abrakadabra, ababatabrb, abrankobo, abmatater, abravilabra, also as abra vilabra, apra vilabra, abra sadabra. Contracting quadrangles are based on the image of the disease withering and subsiding, and there were diverse ways to represent it graphically. One way of representing a letter quadrangle is with two formulae side by side with the number of letters decreasing on the left and increasing on the right. The result was a balanced incantation. Then again, sometimes "re-mirroring" was applied, whereby the formula could be reversely developed back into a whole after it had been dwindled to one letter. In such cases the result was also a balanced incantation based on an image of reversed sickness. The word abrakadabra could have been divided into two equal groups, whereas the right-hand group could include fewer letters. In Estonia, if the word was divided in two, both parts decreased uniformly, or alternatively the left-hand part was retained and the right-hand part dwindled. When the right-hand part reached its conclusion, the dwindling of the left-hand part started. Without exceptions dwindling started from the right-hand part. As a comparison it should be pointed out that in Latvian and Russian tradition the dwindling started on the left; if it started on the right, text was represented as a reversed pyramid (Straubergs 1939: $272 \mathrm{ff}$.). The formula was written on paper or bread and fed to the patient.

Words against malaria.

Abra Catabra

Abra Catabr

Abra Catab

Abra Cata

Abra Cat

Abra Ca

Abrac

Abra

$A b r$

$A b$

A

These words are to be written on a blue or erysipelas-coloured post-office paper and given in so that the person who it is given in to would not know of it. (E 49728 (32) < Võn 1915) 
Typical shapes of abrakadabra:

a)

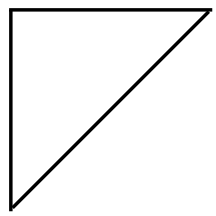

b)

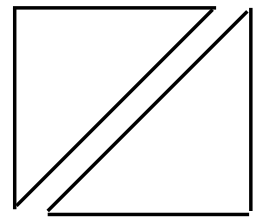

c)

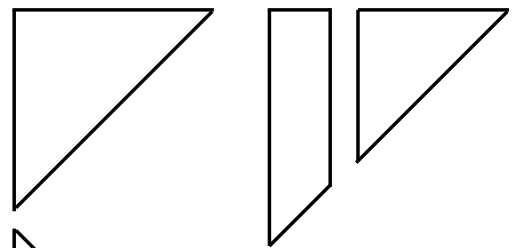

Since the Middle Ages, European incantations have been partly transcripts of gospels and parts of prayer texts (this will not be dealt with here at greater length), and canonical biblical expressions in foreign languages, mostly in Latin, Greek or Hebraic. Alongside with full-scale transcripts letter abbreviations of prayers were used. These were mostly letter formulae composed of initial letters of words and carried along as amulets. Occasionally the formulae were supplemented with magic signs whereby letters were separated from one another by a cross, reversed cross or other signs.

The use of complete prayer texts, and later the use of celestial letters for healing and protection magic is an ancient and generally applied custom in the whole Europe. Prayer texts and transcripts of gospels were carried along since the late antiquities. Hand-written copies of celestial letters were carried along by many soldiers in WW I (Hndb IV 21 ff., VII 1385). The continuum of belief accounts and stories about celestial letters in Estonian tradition include all more widely spread motifs. There is an array of tradition accounts from the beginning of the 20th century about the practical use of the formulae and numerous stories about experimental trials of the "anti-bullet" power of the writing: it was attached to the chest of a conscript or tied to the tail of a cat who was then shot. The tradition holds that the bullet missed. The latest data about celestial letters employed for easing childbirth originate from the year 1986. Today this is a sign not of the decline and death of 
the tradition, which was marginaly by that time, but an indication of the situation of data that has reached the Estonian folklore archives. In the 1990s the Estonians resettled in Russia and Caucasus have contributed reminiscences about protection letters that saved them from bullets and death in WW II; similar letters circulated also among members of free congregations.

The Gospel of St. John as one of the most frequently used parts of the Bible was carried along by deported or conscripted Estonians as a hand-written copy or pocket-edition. The use of this gospel as an avertive formula is a custom several centuries old. More often than not archive texts do not allow determing the exact text in the Bible or the Psalms used in the healing rite, as records are fairly vague, leaving everything but the general title of the source unidentified: /---/ He took the Book of Psalms, chose one psalm and pressed it to me for three times, it immediately removed the pain. (KKI 9, 115 (7) < Vil 1948)

Most prayer texts and letter formulae spread from hand to hand as handwritten copies; they were also used for healing in written form. Records of attempts to read incantations on the ill place are extremely rare. This could obviously be done only if the letters yielded something readable and when the legible was also pronounceable.

The use of complete foreign-language incantations, expressions and shortened prayers as spells was not very common in Estonia. Rather it can be seen as an exception from the general way of using incantations. Thus "Mene, mene tekel" (Daniel 5: 2628) was used as an independent incantation against erysipelas, but it became contaminated by other spells (e.g. sator). The abbreviation for the Agatha prayer MSSHDEPL or Mens Sanctra Spontaneus Honor Dei Et Patriae Liberatio spread in Europe in the 15th century as protection against fire, etc. (Hndb I, 211). It was similarly used in Estonia.

It is singular that shortened prayers and canonical foreign-language expressions used as incantations were multifunctional and used against various diseases. In Estonia some more widely known such incantations were Bin Kristus, Aurora musa, Sieht stiets, Idese bis tridese. There is a considerable number of variants of such incantations: some of the changes and mistakes were due to tran- 


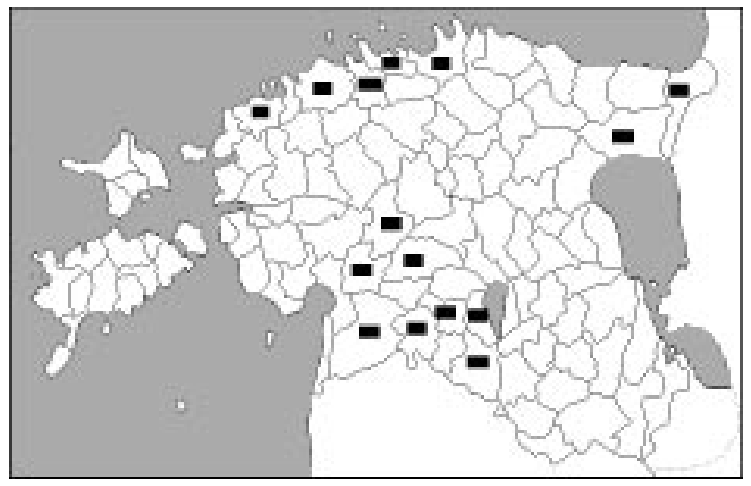

Map 5. Distribution of the Bin Kristus-formula.

scribers not understanding the foreign language or archaic and complex letters and signs; again, words were adapted to the mother tongue. Some representations of Bin Kristus can serve as an example: Bin $x$ Kristus $x$ Pehrtuls $x$ Nomen $x$ Sebusa $x$ Novent $x$ Souus $x$ Maria $x$ Joosepa $x$ (ERA II 70, $121<$ Kul 1933) or Rein, Kristus, Rohituli, Noomen, Neebuskat, Navent, Jeesus, Maarja (E 34310 $<$ Hel 1897) or

Beia Kristus Behetul

Nommen Sebuskat

Vahnet Jeesus Maria

Joosept See Jumala, isa

See Jumala poja, see jumala

See Püha Vaimu nimel. (ERA II 23, 147/8 (6) < Elva < Trv 1926)

In the latter case it has been attempted to represent the incantation as a quadrangle. Despite the distortions the incantation is still Latin-sounding. The Bin Kristus incantation was used to treat erysipelas, bleeding, wounds and other unidentified ailments. It was contaminated with the spell $B x D x J$ (the latter occurs frequently in celestial letters); one modification has a reinforcement formula appended to it. In addition to the above letter formulae incantations append with other formulae. In the following example it has the function of a reinforcement formula.

Jeesusel on tervisesõnad, Jesus has the words of health, Maarjal on Maarja sõnad. Mary has Mary's words. 
Veresooned kinni ja muud sooned lahti!

Sinu raud, sinu maja, sinu rooste,

sinu valu minu taskude.

Poeg Kristus Rohi tuli Amen. Jebuska naven, Jeesus nagelt. J Amen.

(RKM II 322, $29(7)<$ Pst 1976)
Shut the veins and open other vessels! Your metal, your house, your rust, your pain into my pocket. Son Christ Remedy came Amen. Jebuska naven, Jesus nagelt. Amen.

Accounts originate mostly from Pärnumaa and Harjumaa counties and coastal parishes of Lake Peipus.

In Estonian tradition Idese bis tridese was used against snakebite and lumbago. The words are spread in West Estonia and the island of Saaremaa and there is one modification originating from Northwest Estonia (Harju county). This incantation is known also in Latvia (Straubergs 1939: 272).

The ancient origin of Cyrie eleison is indicated by their inclusion in the minutes of witch trials, in the 19th and 20th century the formula was no longer independently used. In its present shape Cyrie eleison is a remnant of past Catholic influences.

\section{HEREH \\ SELES \\ TENET \\ SELAS \\ KÜRJE \\ ELEISON.}

(RKM II 135, $208<$ Har 1962)

Special meaningless spells were used as independent incantations; such words were originally created for incantations and were used only there. Variants of the central word were created by vowel change, initial change or adding letters. Groups of such words were used to create new incantations or added to the usual formulae. Probably the best known example of this in Estonia is maks and the incantation type based on transforming it: maks, paks was used against erysipelas and rabies. In Latvia the respective incantation had two forms mast, past and maks, paks (Straubergs 1939: 275). Maks occurs independently, though sometimes appended to sator, 
etc. Changes in the representation of the formula may amount to shapes like Paes maes, mi paes (H I 7, 382 (7) < Vil 1895); cf. Handb III 1586). Sometimes the unknown word was tried to be relocated into semantically comprehensible environment, as is the case in texts recorded in Vändra and Häädemeeste parishes:

Veri seisab kui üks maks Blood stands solid (3 times)

Oh jumal tee teda kõvaks Oh God make it hard (3 times)

Oh jumal kinnita teda. Oh God make it strong. (3 times)

Words to stop bleeding. To be read for nine times with one breath. Helps for a wound. Or if milk is red, it is read on vodka and given to cattle. It cannot be read on a human, its blood may become solid then. (E, Stk 14, $144(2)<$ Vän 1922)

Verd kinni panna.

Sinu veri mingu kops kõvaks,

maks paksuks nii kui Jeesuse maks.

Amen, amen, amen.
To stop blood.

Let your blood be hard now kops!, maks! as fat as that of Jesus, maks! Amen, amen, amen. (RKM II 166, 189 (32) < Hää 1963)

Besides meaningless spells, there are incomprehensible foreign words traditionally used in incantations. The tradition has a tripartite grounding: (1) texts of old incantation manuscripts; (2) the belief that some cultures, in comparison to their own resources, possess limited but powerful supplies of foreign or alien wisdom; (3) the belief about the supernatural origin of magic formulae, the language of which would not be comprehensible to an ordinary mortal. As mentioned above, in incantations used in German cultural area, Latin, Greek, and Hebraic words and expressions were used alongside with the so-called specific magic formulae. Throughout Estonia also German words have been used; in North-East Estonia, South-East Estonia and the island of Saaremaa there are records of Russian words, and in Harju and Viru counties of Finnish words for a mystic and incomprehensible effect. One such word is used in the incantation 'Türna' birch [or bleeding birch] employed to stop bleeding :

Tü̈̈, tü̈̈ türna kaske, sinista sirisemasta,
Run, run, bleeding birch, Do not trickle blue, 
punasta purisemasta!

Türna jookseb haavikusse

I--- /

(E 57976/7 (4) <Kuu 1926)
Do not ooze red!

Türna will run into aspen grove /--. /

In Karelian dialect türna means bleeding, in Estonian this word has no meaning. In different versions the informant looks for possible interpretations of kask [birch], sometimes changed to kosk [waterfall]. Türnakosk present in texts could here also be understood as verekosk [blood(y) waterfall].

The amount of incomprehensible words used in incantations is increased by using distorted foreign words, e.g. the case of rosa pilla, and through the use of archaic dialect as in the case of türna kask.

In Estonia there are also cases of deliberate invention of incantations and incomprehensible incantation formulae. For instance, there are magic formulae created by Fr. R. Kreutzwald: tollaholla, pilla villa (the German translation goes as Tollaholla, steure Wolle!), or Orra-porra, põrgo händ (in German translation Orraporra, Höllenscheif). These formulae have no counterparts in genuine folk tradition. The author has commented that Tollaholla wahrscheinlich Name ist dem Zauberer dienstbaren Geistes, Orraporra der Name eines Drachen ist (Kreutzwald and Neus 1854: 77). It is noteworthy that Kreutzwald's magic formulae comprise extensive improvisational parts and many of the texts in his collection of incantations are his own creation. Interestingly enough a couple of such incantations have been reprinted in folklore publications and have from there passed into popular usage; this is especially true about incantations for curing snakebite.

Occasionally sacral names were used as magic formulae. Letter formulae are originally connected with sacral, mythical and biblical names. For example, thus in Estonia Elochim was used against cramps, Adonai to treat epilepsy, Iisrael, Iisak was used against rabies.

The use of names in incantations is a separate and intriguing topic. In healing incantations it was possible to include in the text the first name of the subject at whom the incantation was directed. For some reason or another this tradition was longer retained in incantations of clear foreign origin aimed at children. A number of 
incantations list the names of three, seven or nine persons who are seen as possible causes of evil, e.g. words to exorcise a spell, to disrupt hiccups and in other healing words. If the selection included the correct name, the disease would retreat. All formulae listing different natural forces, kinds of wind, snakes of different colours, young men and women with different eye and hair colours can be indirectly subsumed under the same category; however, general or euphemistic names are used instead of real.

Tere, tere maavihake, tere, mullavihake, tere, tulevihake, tere, tukivihake, tere, vinguvihake, tere, auruvihake, tere, koldevihake!

Tere, maa-alused isandad, Hello underground masters, tere, maa-alused emandad, hello underground ladies, tere, maa-alused noored neitsikesed, tere, maa-aluste kuningas! hello the king of the underground! Kust olete tulnud, kas maast või mullast, kas kullast või hõbedast, kas rauast või vasest, kas tinast või terasest, kas rukkist või odrast, kas nisust või kaerast, sinna te üheksamal viisil tagasi minge!

Saa terveks, saa terveks kui $(N)$, kui $(N)$ !

(ERA II 40, $246<$ KJn 1924/5)
Hello, hello earth anger, hello soil anger, hello fire anger, hello brand anger, hello smoke anger, hello steam anger, hello hearth anger!

hello young underground maidens, Where have you come from, of earth or soil, of gold or silver, of iron or copper, of tin or steel, of rye or barley, of wheat or oates in nine ways go back there!

Get well, get well as $(\mathrm{N})$, well as $(\mathrm{N})$ !

In Slavonic incantations the name of the person who carries out the incantation or the name of the subject is included in canonised addressing verses. Guessing or calling the name is the basis for various exorcist incantations against mythological creatures and diseases, and also against animals. Mentioning the name also served as an impairment incantation. 


\section{ESTONIAN FOLK BELIEF AND PHENOMENA RELATED TO LETTER FORMULAE}

Besides letter mysticism, letter formulae are genetically connected with several older forms of belief and magic. Being connected with various areas of religion and belief, letter mysticism spread in many cultural and language domains. It was most probably mediated to Estonia by Germans, though sign symbolism was known before. In our tradition letter mysticism is closely connected with the use of runes, family signs, and so-called magic signs, but also in pictorial magic.

Originally runes were used for writing incantations (Vries 1956: 307). The oldest known Karelian writing on birch bark is a thunder incantation. Tradition concerning Old Germanic runic script points to the existence of a developed letter mysticism which was intertwined with number magic. The cultural tradition in question was familiar with vowel and consonant mysticism and other types of letter mysticism. In later tradition a part of beliefs connected with runes was transferred to the tradition that concerned witchcraft. An example here could be a story of an unskilled craftsman who unleashes a disease through cutting wrong runes into the bark of a tree (Vries 1956: 309) which is comparable to an international motif about an unskilled user of a magic book, also stories about apprentices, servants or other profanes who, in the absence of the owner, read spiritual beings or a disease "out" of the book, or who by mistake disturbed the dead and summoned them (similar Estonian motifs can be found in Eisen 1896). The scope of the usage of runes on Estonian territory is by no means unambiguously clear. In view of cultural contacts and linguistic borrowings at different times (Ränk 1949: $17 \mathrm{ff}$.) it is likely that runes were used for magic purposes. The runic calendars spread in coastal areas were filled in with Scandinavian or so-called Swedish runes and some dates have been designated with interesting additional signs. An account of the oldest printed runic calendar originates from the 17th century and bears traces of coastal Swedish influence (Ränk 1949: 180). Estonia has had consistent coastal Swedish settlement since the 13 th century, whereas Scandinavian influences on material culture and folk belief are traceable back to the Bronze Age (EE 1982: $161 \mathrm{ff}$.). 
Drawing 6. E 49724 (23) < Võn 1915.
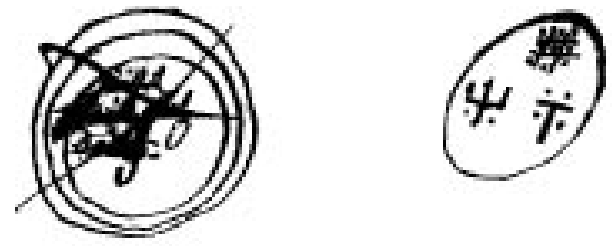

Family signs occasionally coincided with general witchcraft signs, but had initially, alongside with their use for designation and distinguishing movable and immovable property, had the meaning of a sign of protection. Family signs and isolated runic signs have also been added to written spells. Signs made of bent grass or branches were used to designate property in the forest, field or at seaside; the signs were also used for designating property washed ashore. The signs were scratched or drawn on objects belonging to the family, first and foremost on border stones. In 1970s I was personally quite surprised when I observed older heads of households in the village of Kahtla in Saaremaa making family signs on all kinds of objects that had been washed ashore, and similarly on property left in the forest or field which was too cumbersome to be taken along right away, but which had to be protected from being taken by someone else.

In the 19th century magic signs were an integral part of the system of daily customs. The custom to make crosses upon flour, bread, other staples, hay, unfinished work and threshold when leaving home, etc. is sporadically observable also today. It can be said that the custom is followed not so much because of a deeper conviction, but rather because of a need to go by the ancient custom giving continuance to something rooted in the family in the course of many years. Drawing magic signs before incantation, during or after it in order to conclude and confirm the message, to put a stop to the progress of a disease or finish a ritual has been generic and common even in the 20th century. Magic signs were made during the ritual and while reading incantations. However, a larger number and greater variety of signs are connected with written spells, first and foremost letter formulae, legend incantations, and words based on number magic - this aspect will be dealt with at greater length under performance customs. 
Incantations were also related to so-called pictorial magic; it was mostly used in love and hunting magic and less in impairment magic (Eisen 1926: 310, Hämäläinen 1944: 50) where someone's figure was scratched onto wood or birch bark. The latter procedure was mostly accompanied with short formulae.

\section{THE SPREAD OF LETTER FORMULAE}

In the Balto-Finnic area letter formulae, in comparison to the previouosly discussed phenomena, form a relatively new layer of borrowed spells spread mostly through magic books and manuscripts (in German), celestial letters and manuscripts of words of magic.

In oral tradition incantations and magic recipes tend to be connected with the Sixth and Seventh Book of Moses. According to this tradition the Bible initially included six or seven books, whereas the two last books, alongside with magic recipes, contained powerful words. The motif of a handbook by Moses pro Jewish, Egyptian, etc. witchcraft is wide-spread (Anderson 1929: 203) and known since the first centuries A.D. Indeed, manuscripts and later printed documents allegedly containing ancient Jewish, Egyptian and Greek words of wisdom circulated at that time. The tradition holds that the texts used by Moses for releasing his people from Egyptian serfdom were a part of these manuscripts. Some of the popular editions circulating in mediaeval Europe were brought to the Baltic region by German colonists.

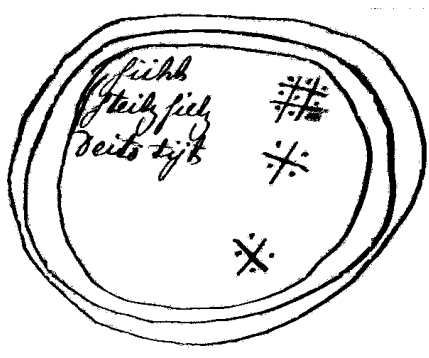

Drawing 7. E 49724 (23) < Võn 1915. 
The Sixth and Seventh Books of Moses, popular and also feared in folklore and tradition, were used by folk healers to bolster their authority and incantations. They claimed using the given extremely rare manuscript to find healing words and therapeutic methods. It is not easy to determine which source was actually used, but it is true that the popular edition of the Book of Moses has been applied in the healing rite alongside with bulkier publications, including editions of the Bible in foreign languages and the first Bible in Estonian. Tradition has evaluated the latter as especially powerful, as it contained seven books instead of five - the two missing books being removed and thereafter destroyed at the order of landlords or priests for fear of witchcraft. The tradition held that single copies of the Bible containing the secret wisdom were hidden and thus stayed with the people. At some places the existence of a powerful book of witchcraft is still believed today.

The spread of magic books has been observed in Germany, but not in Estonia. Thus all generalisations are to be based on accounts recorded from mediators, folk healers, and the few copies that have been archived or discovered in the course of fieldwork. Popular widespread editions of magic books in Estonia were Sechstes und siebentes Buch der Mosis, Das wahrhaftige feuerige Drache, Romanus-Büchlein, Geheime Kunst-Schule magischer WunderKräfte, etc.; many copies show signs of heavy use, i.e. underlinings and exclamation marks in the margins, etc. The first books in the list can be considered to have been mediations of cabalist wisdom. Besides beliefs and magic instruction the magic books usually included spells in general and letter formulae in particular. Such publications have mediated data in several different periods. For instance, the sator-formula was first printed in Estonia by O. W. Masing at the beginning of the 19th century (Põldmäe 1938: 114) with the purpose of denigrating the custom. Later the incantation was published in "The Seventh Book of Moses" printed in Estonia for three times $(1872,1912,1997)$; the incantation has found its way into tradition through these publications. (A survey of the tradition concerning the Sixth and Seventh Books of Moses can be found in a collection of texts compiled by M. J. Eisen (Eisen 1896)). I have pointed out that such publications have been actual sources 
of beliefs and actually applied magic rituals. For example, healer Tiitsu Seiu from the island of Saaremaa had enthusiastically tested several recipes of popular editions and had found there the crucial part of her healing rite - the sator-words (Kõiva 1989: 94).

Letter formulae were also spread through celestial letters. These Christian pseudographies, initially meant as propaganda for celebrating Saturday, were later appended by the dream of Virgin Mary, the list of ill days and protective spells against fire, bleeding, thunder, wounds from sword and bullet. It was recommended to carry celestial letters along at the time of childbirth. The spread of the manuscript was facilitated by the requirement to pass it on in written form. Rudolf Põldmäe argued that celestial letters in Estonian and Latvian were spread in the Baltic area through the mediation of Baltic Germans at the end of the 18th century and at the beginning of the 19th century. In 1822-1825 the press and the clergy put up an angry fight against the spread of celestial letters; the full text of a celestial letter published by $\mathrm{O}$. W. Masing gave boost to the spread of similar letters among peasantry (Põldmäe 1938: 104). Initially only hymns and trivial notes, later also spells, were written into notebooks (see for example, RKMAK $163<$ Ridala 1976).

(Features typical of protection letters can be found in some chain letters, especially in string letters of clerical content of which, in order to achieve protection, a certain number of copies was to be made and forwarded to acquaintances. Promises to reward the spreading of the letter by success, money or happiness and threats of disease or mishap if the chain is disrupted are common also in the case of ordinary chain letters (Anderson 1937: 5, Kõiva 1994: $13 \mathrm{ff}$.$) ).$

\section{SOME OBSERVATIONS ON THE USE OF LETTER FORMULAE}

The domain and ways of application of letter formulae were certainly limited. They were mostly used as healing words and, as the incantations were known only to mediators with special skills, only in cases when it was possible to wait for medical assistance, when 
the treatment involved immediate influencing of the ill place, or when it was not possible to treat the disease without professional help. Letter formulae were used to heal or alleviate erysipelas, malaria, rabies, lumbago, shock, cramps and epilepsy, toothache, fever, labour pains, bleeding, wounds, swelling, inflamed finger, sprains, bone-ache, snakebite, stroke, and cows' bladder diseases with blood in stale. In other cases incantations have been used against fire, to improve spoilt milk, against the wrath of landlord, in hunting and love magic, and as protection against various disasters; however, accounts of such uses are relatively scarce.

Letter formulae differ from other incantations not only in their religious background and origin but also in the specific complex way they were used. As compared to other words written incantations are connected with magic signs. In fact, drawing signs and their significance as one of the pivotal points of the ritual is in the case of letter formulae much clearer than in association with other types of incantations. In healing and protective rites magic signs have actually replaced incantations, as signs of witchcraft and letter formulae are to an extent identifiable with each other and occasionally their function is comparable to that of mandala.

You have to draw seven triangles on blue paper, just about like this. Then, reading out the Lord's Prayer, you have to paint all triangles black with a pencil and put them on the erysipelas. At that time you have to recite Lord's Prayer backwards for three times. (E 82488 (1) < Vän 1933)

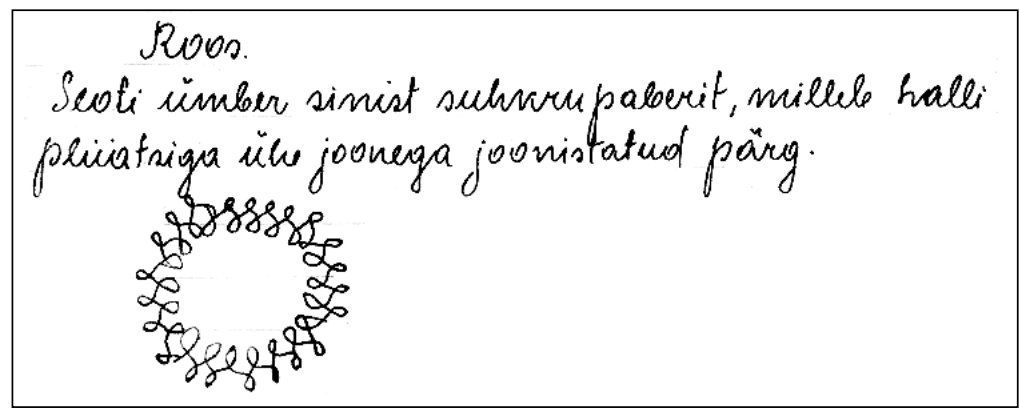

Drawing 8. ALS 3, $52<$ Sim. 
The religious and ethnographic material and records on folk belief include seven prevalent magic signs (Kurfeldt-Hanko 1938: 366 ff.). The sign of the cross has been used in nearly all types of situations, for both negative and positive purposes: healing, protection, promotion, and impairment magic. Cross, pentagram, loop quadrangle (or any other loop polygon), and less frequently octagon and sexagon was used for healing without adding spells. The healing rite might have included incantation, but not necessarily, depending on the skills of the healer, the healing situation and the method chosen for the rite. Cross, pentagram, triangle and some of the loops were most frequently used for the treatment of dermatological diseases (erysipelas, scabs, warts, herpes, furuncles, moth (nahakoi), eczema, "the disease of the underground people" (maalised), etc.) but also for treating sprains, snakebite and other traumas ans as was mentioned above, the words could be omitted altogether, since the sign itself had the necessary influence. To bring just one example: When it is desirable that a hunter should miss the target, without his seeing it, a pentagram is drawn on the target with earwax. (H III 18, 373 (7) < Vig 1894)

Magic signs, again with or without accompanying magic formulae, were also used in transition and crises rites and in daily customs. During critical times, especially when starting or finishing different works, they were drawn on the doors of houses, barns and cattle sheds, on dishes (Eisen 1931: $35 \mathrm{ff}$.), and on specially stored sheaves, etc. in order to protect ritual and daily food. The Christmas pork serving as a ritual bread was covered with signs (Eisen 1931: 36). Magic signs were a part of the tradition associated with the beginning and end of the period of tending grazing cattle, the starting and finishing of harvest, etc. The use of cross (or pentagram) was a part of this tradition and accompanied the incantation. At the beginning of the 20th century swastika was used together with impairment words (Kurfeldt-Hanko 1938: 377).

In incantation, healing rites, and at different works, circles, pentagrams, loops and other magic signs were drawn while reading out the words. However, this was done at different phases of performing an incantation: before the incantation, after a certain part of the formula and at the end of the incantation, after reading certain parts of the incantation and at the very end, or only at the end of 
the incantation. The signs and encircling could be made for a certain number of times - for exactly as many times as the incantation was repeated - thus always before repeating the text. If only the accompanying activity was altered and not the text, the signs were made before proceeding with the new activity.

Looking at the healing ritual as a whole, in the case of letter formulae the signs are also repeated before the beginning of the rite, during the rite at the beginning of a new accompanying activity or a portion of text and at the end of the rite. They could be drawn after certain units of text in order to separate letters, words, verses, sentences or different incantations. An incantation became effective only in combination with signs.

$B \times D \times I \times W \times K \times J \times B \times O o \times K \times$ (ERA II 70, $105<$ Kul 1933)

Magama panemise sõnad. The words for lulling to sleep.

Uni sind toitku $\dagger$ Let the sleep feed you $\dagger$

Uni sind täitku $\mathrm{t}$, Let the sleep fill you +

Uni sind kaitsku kurja eest $\uparrow$ Let the sleep protect you from evil $\uparrow$ maga nii kaua kui $\dagger$ sleep as long as $\dagger$

Here the performer of witchcraft says the oath how he could be waken up again. /---/

(EKS $4^{\circ} 5$, $33(49)<$ Krj 1888)

Especially frequent was the use of signs, mostly the sign of cross, to separate the reinforcement formula from the rest of the text.

In the name of Father, Son and the Holy Ghost, the servant of Jehovah of Israel is the golden crown man of king. The moon is the spirit of kukrun (the Morning Star). Amen +t† The moon extinguishes, the day shines, the dawn clarifies. The God of Israel, send us help t. (H III 1, 1/2 (7) < Krl 1895)

As mentioned above, in drawing the signs, reading the words, and accompanying customs repetition for a certain number of times was important: just as texts (or their parts) were read a certain number of times (three, seven, or nine), it was important to draw a correct number of magic signs and to locate them in the correct part of the ritual. Triple repetitions dominate but signs were also 
drawn for seven or nine times. Signs were made with graphite, coal, pencil or paint, often fingers or sharp metal objects were used. The following are some examples of such activities:

The healing instruments were an ordinary (not indelible) pencil, it had to be blue, and a cover of an ordinary school notebook. On this paper the informant wrote four or five lines and then crossed them out so thoroughly that not a single word was legible. This paper was then put upon the ailing part with the writing facing downwards and usually tied up with a scarf or some thicker cloth./---/ Those who had come from more distant regions got the paper with them for the fear of its (erysipelas) reoccurrence and they were told to burn the paper later. Sometimes the healer made no use of paper, but neared his mouth to erysipelas and the movement of his lips made it possible to conclude that he read something - doing it so quietly that even the patient could not hear anything. (RKM II 106, 132/4 (11) < Vi, Kohtla-Järve 1960)

/---/ with erysipelas the blisters were covered with blue paper, a pentagram was scribbled on it and words were read and then silk of nine colours was tied around it. (RKM I 18, 106 (VI) < Iis 1981)

All kinds of strange spirals and crosses were drawn on it. (RKM II 351, 437 < Jür 1981)

The magic place was also encircled, with words and symbols scribbled on it. (RKM II 354, 414 (6) < Trv 1958/9)

He brought white paper and drew pentagrams on it with a black pencil, he scribbled all the time so that the paper was filled with pentagrams, so that it was all done with the same pencil. (RKM II 359, $27(24)<$ Plt 1981)

Nine circles are drawn with a pencil on blue paper. On the circles three crosses are made with the pencil. (RKM II 279, 451/2 $(267 b)<\operatorname{Trt} 1969)$

Less frequently also other types of incantation had fixed patterns of graphic representation. The words were written as quadrangles, triangles, spirals, labyrinths, loop polygons, circles and in various other shapes. 
Letter formulae were contaminated by incantations of very different origin and structure, oral incantations as well as others. Thus a healing ritual could make use of a mixture of written or "applied" incantations and oral incantations. Usually contaminations involved 2-5 separate incantations. Most often a letter formula was written just once, whereas other incantations might have been read for three and more times in accordance with the requirements of the healing rite. Letter formulae could be carried along under clothes, fastened on living premises, trees, or written on tables, plates and elsewhere as was pointed out in the case of sator and abbreviations derived from prayers.

Earlier the words were written first and foremost on blue paper (the so-called sugar-loaf paper) and hermetically sealed onto the ailing organ. The paper carrying the formula could also be burnt in which case the patient was to take in the ashes. When the letter formula was written on a bread (or sandwich) or on the so-called magnetised water (vodka), then it was usually given to the patient to drink and less frequently used for the external treatment of the ailing part.

\section{CONCLUSION}

Letter formulae are based on ancient religious images and are connected with some of them (protection and witchcraft signs, pictorial magic) up to the present day. The origin of letter formulae is associated with the perception of letters as mysterious and mystical phenomena which was a view supported by the teaching of cabalists. Letter formulae are closely connected with gnosticism and cabalism. In the European cultural area evidence on the early spread of letter formulae could be found; however, similarly to other incantations they spread in greater numbers during the Middle Ages, mostly in the 14th and 15th centuries, when esoteric knowledge became increasingly diluted and simplified. It is likely that the spread and establishment of incantations well-known in Europe was fairly slow in Estonian tradition as the first references to them are found as late as in the 18th century. The spread of the formulae was facilitated by printed sources and religious movement, notably the pietist movements. There is a significant pro- 
portion of incantations similar to Latin, Greek and Hebraic, the contents of which probably was not accessible to most performers and mediators of the tradition. Such incantations were rather performed like ancient sacred formulae or mantras.

In the case of letter formulae we are dealing with an esoteric groupbound folk tradition which did not form a part of daily universally accessible repertoire. Letter formulae were used for the treatment of more serious diseases (rabies, cramps, epilepsy, erysipelas, bleeding and wounds). These formulae were not part of the skills of every folk healer and some of them were in handwritten form passed from hand to hand by people involved in the pietist movement. This is a point of connection between healing words in the sense of incantation and healing words understood as a prayer or holy text of Christian origin.

The spread of incantations in writing is connected with the use of written incantations. Letter formulae are neither long nor complicated, but their foreign quality contributes to a higher-than-average variability of the texts. The degree of variability and contamination is increased by attempts to find meanings closer to the mother tongue for texts in a foreign language or with an archaic ring. Older and better-established types of incantations have intermingled or become contaminated by different types of spells of different origin yielding new complete incantations of motley form and content. The spread of specific types of incantations is different and individual; generally higher concentrations can be observed in West-Estonia and Saaremaa.

\section{References}

Anderson, W. 1929. Das sechste und siebente Buch Mosis in Norwegen. Opetatud Eesti Seltsi Aastaraamat 1928. Tartu, pp. 203204.

Anderson, W. 1937. Kettenbriefe in Ehstland. Tartu.

Astakhova, A. 1928. Zagovornoe iskusstvo na reke Pinege. Krestianskoje iskusstvo SSSR. Iskusstvo Severa. Vyp. 2. Leningrad, pp. 50-60. 
Dornseiff, F. 1985. Das Alphabet in Mystik und Magie. Zweite Auflage. Leipzig-Berlin.

EE 1982 = Jaanits, L. et al. 1982. Eesti esiajalugu. Tallinn.

Eisen 1896. Seitse Moosese raamatut. Katse kuuenda ja seitsmenda Moosese raamatu seletuseks. Tallinn.

Eisen, M. J. 1926. Vahakujud ja pildid. Eesti Kirjandus, No. 6, pp. 307-317.

Eisen, M. J. 1931. Meie jõulud. Tartu.

Eisen, M. J. 1934. Sator-nõiasõnad. Eesti Rahva Muuseumi Aastaraamat IX-X. Tartu, pp. 81-96.

Gagulašvili, I. 1983. Gruzinskaia magicheskaia poezia. Tbilisi.

Hndwb = Hoffmann-Krayer, E. \& Bächtold-Stäubli, H. Handwörterbuch des deutsches Aberglaubens. I-IX. Berlin-Leipzig 19271938.

Hämäläinen, A. 1944. Menschen- und Tierförmige Abbilder in Magie und Kult der finnisch-ugrischen Völker. Mitteilungen des Vereins für finnische Volkskunde nr. 3-4. Helsinki, pp. 33-52.

Kreutzwald, Fr. R. \& Neus, H. 1854. Mythische und magische Lieder der Ehsten. St. Petersburg.

Kurfeldt-Hanko, J. 1938. Nõiamärkidest. Eesti Kirjandus, No. 8, pp. 365-377; No. 9, pp. 403-415.

Kõiva, M. 1989. Aleksei Lesest ehk Tiitsu Seiust. Paar sammukest eesti kirjanduse uurimise teed. XII. Jakob Hurda 150. sünniaastapäevaks. Tallinn, pp. 80-100.

Kõiva, M. 1994. Õnnel pole hinda. Koolipärimus. Pro folkloristica I. Tartu, pp. 12-15.

Peskov, A. 1977. Ob ustoichivykh poeticheskikh elementakh russkogo zagovora. Filologia, vyp. 5. Moskva, pp. 26-38.

Peskov, A. 1980. Zagovory. Obriadovaia poezija Pinezhia. Materialy fol'klornykh ekspeditsii MGUv Pinezhkii raion Arhangel'skoi oblasti. (1970-1972 gg.) Moskva, pp. 161-175.

Poznanski, N. 1917. Zagovory. Opyt issledovania proishozhdenia i razvitia zagovornykh fol'klornykh formul. Peterburg.

Põldmäe, R. 1938. Die früheste Verbreitung der Himmelsbriefe in Estland. Acta Ethnologica. København, pp. 100-115.

Ränk, G. 1949. Vana eesti rahvas ja kultuur. Stockholm.

Seligmann, S. 1910. Der böse Blick und Verwandtes. Ein Beitrag zur Geschichte des Aberglaubens aller Zeiten und Völker. Berlin. 
Straubergs, K. 1939, 1941. Latviešu buramie vardi. I, II. Riga. Vries, Jan de 1956, 1957. Altgermanische Religionsgeschichte. I, II. Zweite Auflag. Berlin.

Wuttke, A. 1925. Der deutsche Volksaberglaube der Gegenwart. Leipzig. 